\title{
Short communication: Effects of processing methods of barley grain in starter diets on feed intake and performance of dairy calves
}

\author{
A. Jarrah, ${ }^{*}$ G. R. Ghorbani, ${ }^{*}$ P. Rezamand, $\dagger^{1}$ and M. Khorvash* \\ *Department of Animal Sciences, Isfahan University of Technology, Isfahan 84156, Iran \\ †Department of Animal and Veterinary Science, University of Idaho, Moscow 83844
}

\begin{abstract}
The present study was conducted to evaluate the effects of different processing methods of barley grain in starter rations on feed intake, average daily gain, feed efficiency, skeletal growth, fecal score, and rumen $\mathrm{pH}$ of dairy calves. Thirty-two Holstein dairy calves (16 female and 16 male) were randomly allocated to 1 of 4 treatments consisting of coarse ground, whole, steam-rolled, or roasted barley from d 4 to 56 of birth in a completely randomized design. Starter diets were formulated to have similar ingredients and composition. All calves had free access to water and feed throughout the study period and received $4 \mathrm{~L}$ of milk/d from a bottle from d 4 to $41,2 \mathrm{~L} / \mathrm{d}$ from d 41 to 45 , and weaning occurred on d 45. Feed intake and fecal score were recorded daily. Body weight and skeletal growth measures were recorded on d 4 (beginning of the study), 45, and 56. Rumen fluid and blood samples were collected on d 35, 45, and 56. Data were analyzed using PROC MIXED of SAS (SAS Institute Inc., Cary, NC). The results indicate that different methods of processing barley had no detectable effect on dry matter intake, average daily gain, and feed efficiency and that skeletal growth, health, and rumen $\mathrm{pH}$ were not affected by dietary treatments. In conclusion, the results show that different processing methods of barley included in starter diets had no detectable effect on the performance of dairy calves under our experimental conditions. Therefore, feeding whole or coarsely ground barley would be a more economical method compared with steam rolled or roasted barley.
\end{abstract}

Key words: dairy calf, starter diet, processed barley

\section{Short Communication}

Early transition from monogastric digestion to a functional rumen microbial degradation in dairy calves is important for economic reasons (Khan et al., 2007).

Received January 30, 2013.

Accepted July 12, 2013.

${ }^{1}$ Corresponding author: rezamand@uidaho.edu
Consumption of solid feed, especially concentrate or high-carbohydrate diets, stimulates rumen microbial proliferation and VFA production, and subsequently initiates rumen development in neonatal calves (Harrison et al., 1960). Cereal grains are the primary source of starch in ruminant diets; corn, rice, barley, wheat, oats, and sorghum are commonly used worldwide as starch sources in animal feeds including calf starters (Huntington, 1997). Mechanical and chemical alterations during processing increase surface area exposure and improve ruminal, intestinal, and total-tract starch digestibility of seed grains (Huntington, 1997; Owens et al., 1997). Grain processing methods and degree of processing influence DMI and digestibility. Reis and Combs (2000) reported that starch digestibility was the highest for steam-flaked grains, followed by finely ground and dry-rolled grains, and was the lowest for whole grains. In contrast, feeding raw, roasted or conglomerated sorghum grain resulted in no effects on calf performance or rumen and blood metabolites (Abdelgadir and Morrill, 1995). Limited data are available regarding the effects of processing method of barley on feed intake and performance measures in dairy calves. Therefore, the objective of the present study was to determine the effects of 4 different processing methods of barley on feed intake, growth performance, blood metabolites, and rumen $\mathrm{pH}$ in Holstein calves.

Thirty-two 4-d-old Holstein dairy calves (16 female and 16 male) were used in a completely randomized design from May to August 2011. Calves were randomly allocated to 1 of the 4 treatments consisting of coarse ground (CGB), whole (WB), steam-rolled (SRB), or roasted barley (RB) from d 4 to 56 . Calves were separated from their dams shortly after birth and randomly assigned to individual pens $(1.5 \times 2.8 \mathrm{~m})$ bedded with wood shavings that were renewed, as required (every 24-48 h). Physical contact among calves was minimized by pen arrangement. All calves received $6 \mathrm{~L}$ of colostrum within $12 \mathrm{~h}$ of birth and then $4 \mathrm{~L}$ of fresh milk/d from a bottle from d 4 to 41, and $2 \mathrm{~L} / \mathrm{d}$ from $\mathrm{d} 41$ to 45 ; weaning occurred on d 45 . Free access to fresh water was provided every day. Calf starter was offered ad libitum, and intake was recorded daily, beginning 
Table 1. Ingredients of calf starter (batch records) with different forms of processed barley: whole (WB), coarse ground (CGB), steam-rolled (SRB), and roasted (RB) barley

\begin{tabular}{|c|c|c|c|c|}
\hline \multirow[b]{2}{*}{ Ingredient $^{1}$ ( $\%$ of starter DM) } & \multicolumn{4}{|c|}{ Calf starter } \\
\hline & WB & CGB & SRB & $\mathrm{RB}$ \\
\hline Whole barley & 66.1 & - & - & - \\
\hline Coarse ground barley & - & 66.1 & - & - \\
\hline Steam-rolled barley & - & - & 66.1 & - \\
\hline Roasted barley & - & - & - & 66.1 \\
\hline Soybean meal & 24.0 & 24.0 & 24.0 & 24.0 \\
\hline Soybeans & 4 & 4 & 4 & 4 \\
\hline Wheat bran & 3 & 3 & 3 & 3 \\
\hline Calcium carbonate & 1.9 & 1.9 & 1.9 & 1.9 \\
\hline Monocalcium phosphate & 0.3 & 0.3 & 0.3 & 0.3 \\
\hline Premix (vitamins and minerals) ${ }^{2}$ & 0.5 & 0.5 & 0.5 & 0.5 \\
\hline Salt & 0.3 & 0.3 & 0.3 & 0.3 \\
\hline
\end{tabular}

on d 4. Starter diets were formulated to contain the same ingredients and have similar composition (Table 1). Calf starters contained $66.1 \%$ (DM basis) barley from different processing methods, including WB, CGB [processing index (PI; as defined by Wang et al., 2003) $=$ 90.07], SRB (PI = 59.96), and RB $(\mathrm{PI}=84.97)$. The other components of the diet were in meal form. Barley grain (Hordeum spp.; 2,000 kg) was purchased from a vendor (Poshtibani Omour Dam; Isfahan, Iran) and divided into four $500-\mathrm{kg}$ batches to be processed. Barley grain was ground using a conventional hammer mill (model 5543 GEN; Isfahan Dasht, Isfahan, Iran) with a standard screen size of $1 \mathrm{~mm}$. Barley grains were screened during 2 separate steps and steamed for a minimum of $5 \mathrm{~min}$ at $102^{\circ} \mathrm{C}$ within a 4 -m-high stainless steel chamber directly above the rollers. Steamed grains had a moisture content of 18 to $20 \%$ as they were rolled between preheated corrugated rollers $(46 \times$ $90 \mathrm{~cm}$; Harris Co., Coalinga, CA). Rolled grains were passed through a channel under air pressure and were allowed to dry before storage and subsequent use in the diet. The barley grain fed in this trial was either unroasted or roasted using a mobile system consisting of a propane-fired roaster with a throughput rate of $8 \mathrm{t} / \mathrm{h}$. The barley kernels passed directly through the propane flame for $30 \mathrm{~min}$ (approximate flame temperature of $450^{\circ} \mathrm{C}$ ) and were heated to a temperature of $135^{\circ} \mathrm{C}$ when exiting the roaster. The starter diets were sampled for DM (oven drying at $60^{\circ} \mathrm{C}$ for $48 \mathrm{~h}$ ), NDF (Van Soest et al., 1991; using heat-stable $\alpha$-amylase and sodium sulfate), and ADF (method 973.18; AOAC 1990), ether extract (AOAC, 1990; using a Tecator Soxtec System HT 1043 extraction unit by Tecator, Foss North America, Eden Prairie, MN), and CP (1030 micro-Kjeldahl autoanalyzer; Tecator, Foss North
America) analyses (Table 2). All procedures involving animals were conducted under protocols approved by the Animal Care Advisory Committee of Isfahan University of Technology (Isfahan, Iran).

To monitor calf health, fecal scoring (Larson et al., 1977) was used on a daily basis. Scoring was as follows: $1=$ hard, $2=$ normal, $3=$ soft to loose and watery, 4 $=$ watery mucous, and $5=$ watery mucous and bloody. No measurement was performed regarding the presence of grain in feces. The BW was measured at 3 different time points, including at d 4, 45, and 56. The skeletal growth indices (body length, body barrel, hearth girth, hip height, and hip width; Khan et al., 2011) were measured on d 4, 45, and 56 . Blood samples $(7 \mathrm{~mL})$ were collected $3 \mathrm{~h}$ after the morning feeding via jugular vein on d 35, 45, and 56. Blood samples were placed on ice immediately after collection and centrifuged at 4,500 $\times$ $g$ for $15 \mathrm{~min}$ at $4^{\circ} \mathrm{C}$ to harvest serum. The serum was then stored at $-20^{\circ} \mathrm{C}$ until analyzed for blood metabolites. Blood urea nitrogen and glucose were measured using Pars Azmoon kits according to the manufacturer's procedures (Pars Azmoon Co., Tehran, Iran). The concentration of BHBA was measured using commercial kit (Randox Laboratories Ltd., London, UK) with a Technicon-RA 1000 Autoanalyzer (DRG Co., Marburg, Germany). Ruminal fluid ( $8 \mathrm{~mL}$ ) was obtained via stomach tube on d 35, 45, and 56, approximately $4 \mathrm{~h}$ after morning feeding, which was done at $0800 \mathrm{~h}$. Rumen fluid $\mathrm{pH}$ was immediately determined $(\mathrm{pH}$ meter model M90; Corning Inc., Corning, NY). Ruminal fluid $(8 \mathrm{~mL})$ was then placed into bottles containing $2 \mathrm{~mL}$ of $25 \%$ metaphosphoric acid and stored at $-20^{\circ} \mathrm{C}$ until VFA and $\mathrm{NH}_{3}$ analyses were conducted.

Data for intake, ADG, feed efficiency (FE), skeletal growth, $\mathrm{pH}$ of rumen fluid, and blood metabolites (glu- 
Table 2. Least squares means for BW, ADG, DMI, and feed efficiency (FE) of Holstein calves receiving calf starter containing whole (WB), coarse ground (CGB), steam-rolled (SRB), or roasted (RB) barley

\begin{tabular}{|c|c|c|c|c|c|c|}
\hline \multirow[b]{2}{*}{ Item } & \multicolumn{4}{|c|}{ Calf starter } & \multirow[b]{2}{*}{ SEM } & \multirow[b]{2}{*}{$P$-value } \\
\hline & WB & CGB & $\mathrm{SRB}$ & $\mathrm{RB}$ & & \\
\hline \multicolumn{7}{|l|}{ BW (kg) } \\
\hline Initial & 40.3 & 42.2 & 40.7 & 42.6 & 1.04 & 0.34 \\
\hline Weaning & 62.4 & 63.1 & 64.0 & 61.3 & 2.21 & 0.83 \\
\hline Final & 68.5 & 72.2 & 72.15 & 70.1 & 2.66 & 0.49 \\
\hline \multicolumn{7}{|l|}{ ADG $(\mathrm{kg} / \mathrm{d})$} \\
\hline Preweaning & 0.47 & 0.49 & 0.51 & 0.45 & 0.04 & 0.78 \\
\hline Postweaning & 0.50 & 0.76 & 0.67 & 0.73 & 0.08 & 0.18 \\
\hline Overall period & 0.48 & 0.54 & 0.54 & 0.51 & 0.04 & 0.67 \\
\hline \multicolumn{7}{|l|}{ DMI $(\mathrm{kg} / \mathrm{d})$} \\
\hline Milk & 0.48 & 0.48 & 0.48 & 0.48 & 0.13 & 0.76 \\
\hline \multicolumn{7}{|l|}{ Starter } \\
\hline Preweaning & 0.35 & 0.39 & 0.37 & 0.40 & 0.05 & 0.87 \\
\hline Postweaning & 1.37 & 1.64 & 1.48 & 1.56 & 0.12 & 0.48 \\
\hline Overall period & 0.57 & 0.65 & 0.61 & 0.65 & 0.06 & 0.70 \\
\hline \multicolumn{7}{|l|}{ Total DMI (kg/d) } \\
\hline Preweaning & 0.85 & 0.88 & 0.87 & 0.90 & 0.05 & 0.87 \\
\hline Postweaning & 1.37 & 1.64 & 1.48 & 1.56 & 0.12 & 0.54 \\
\hline Overall period & 0.96 & 1.05 & 1.0 & 1.04 & 0.06 & 0.74 \\
\hline \multicolumn{7}{|l|}{$\mathrm{FE}$} \\
\hline Preweaning & 0.55 & 0.54 & 0.58 & 0.48 & 0.03 & 0.15 \\
\hline Postweaning & 0.34 & 0.46 & 0.43 & 0.47 & 0.04 & 0.11 \\
\hline Overall period & 0.49 & 0.52 & 0.54 & 0.47 & 0.02 & 0.22 \\
\hline
\end{tabular}

cose, BHBA, and BUN) were analyzed as a completely randomized design by PROC MIXED of SAS (version 9.2; SAS Institute Inc., Cary, NC). The statistical model used for analyses was $\mathrm{X}_{\mathrm{ij}}=\mu+\tau_{\mathrm{j}}+\varepsilon_{\mathrm{ij}}$, where $\mathrm{X}_{\mathrm{ij}}=$ dependent variable, $\mu=$ overall mean, $\tau_{\mathrm{j}}=$ treatment $\mathrm{j}$, and $\varepsilon_{i j}=$ residual. Calf was considered as random effect. Birth weight was included in the model as a covariate for pre- and postweaning and overall intake, ADG, and FE. Data for intake, blood metabolites, ADG, and FE were analyzed in 3 sets: before weaning (d 4-45), postweaning (d 45-56), and overall period (d 4-56). Similarly, birth skeletal growth factor was included in the model as covariate for final and change skeletal growth analyses. Significance was declared as $P<0.05$. Data are presented as least squares means \pm standard error of the mean. When a significant treatment effect $(P<0.05)$ was observed, separation of least squares means for significant effects was accomplished using the Tukey option within PROC MIXED of SAS.

Starter diets were formulated to contain the same ingredients and composition (Table 1). Diets containing WB, CGB, SRB, and RB contained 95.5, 95.9, 96.2, and $98.2 \% \mathrm{DM}$, respectively. Diets contained (on a DM basis) $21.1 \%$ CP, $23 \%$ NDF, $47.2 \%$ nitrogen-free extract, $2.7 \%$ ether extract, $0.88 \% \mathrm{Ca}, 0.57 \% \mathrm{P}$, and calculated $\mathrm{ME}$ of 2.78 and calculated $\mathrm{NE}_{\mathrm{G}}$ of 1.21 Mcal $/ \mathrm{kg}$. Starters contained $66.07 \%$ barley with different physical processing methods, as specified.

Least squares means for BW, ADG, FE, milk intake, starter, and total DMI on d 4, 45, and 56 are presented in Table 2. No treatment effect was detected over the preweaning period on ADG, FE, milk intake, or total DMI $(P>0.05)$. Lack of treatment effect on growth and other measurements may have been related to the low statistical power of this experiment, as few animals per treatment group were used.

Over this time period, the greatest amount of starter intake numerically was observed for calves receiving RB, followed by CGB, SRB, and WB. Further, no treatment effect was detected on ADG, starter intake, or FE. Final BW did not differ among treatments $(P$ $>0.05)$ either.

The feed processes may not have had any effects on the rate of fermentation and degradation because newborn calves naturally chew feed more frequently than older calves; perhaps the physical form of barley grains offered may have provided similar nutrient availability relative to calf growth. As calves get older, the processing of barley grains could have an important role in fermentation in the gastrointestinal system. Similar results were reported by (Theurer, 1986; Owens et al., 1997; Zhang et al., 2010). Results reported by Lesmeister and Heinrichs (2004) are in disagreement with results obtained in the present study: in their study, overall starter, DMI, and ADG were different for animals receiving processed grain (corn) compared with animals receiving the whole grain treatment. This disagreement could be related to the type of grain (corn vs. barley) or the level of inclusion (33 vs. 66\%) used in each of the studies. 
Table 3. Least squares means for skeletal growth measurements (in $\mathrm{cm}$ ) of Holstein calves receiving calf starter containing whole (WB), coarse ground (CGB), steam-rolled (SRB), or roasted (RB) barley

\begin{tabular}{|c|c|c|c|c|c|c|}
\hline \multirow[b]{2}{*}{ Item } & \multicolumn{4}{|c|}{ Calf starter } & \multirow[b]{2}{*}{ SEM } & \multirow[b]{2}{*}{$P$-value } \\
\hline & WB & CGB & SRB & $\mathrm{RB}$ & & \\
\hline \multicolumn{7}{|c|}{ Body height } \\
\hline Initial & 76.9 & 78.7 & 79.5 & 78.8 & 0.69 & 0.07 \\
\hline Final & 88.0 & 89.9 & 88.6 & 88.2 & 0.83 & 0.07 \\
\hline Change & 11.1 & 11.2 & 9.0 & 9.4 & 0.69 & 0.30 \\
\hline \multicolumn{7}{|l|}{ Hip height } \\
\hline Initial & 81.0 & 83.1 & 83.1 & 81.9 & 0.76 & 0.17 \\
\hline Final & 91.6 & 93.1 & 93.5 & 93.1 & 0.88 & 0.14 \\
\hline Change & 10.6 & 9.9 & 10.4 & 11.1 & 0.92 & 0.89 \\
\hline \multicolumn{7}{|l|}{ Hip width } \\
\hline Initial & 18.7 & 18.7 & 18.6 & 19.4 & 0.30 & 0.30 \\
\hline Final & 21.3 & 21.3 & 21.4 & 21.4 & 0.24 & 0.46 \\
\hline Change & 2.7 & 2.6 & 2.8 & 2.0 & 0.19 & 0.72 \\
\hline \multicolumn{7}{|c|}{ Body length } \\
\hline Initial & 62.1 & 64.2 & 63.0 & 64.0 & 0.68 & 0.14 \\
\hline Final & 73.9 & 76.2 & 74.9 & 74.1 & 0.79 & 0.07 \\
\hline Change & 11.8 & 12.0 & 12.0 & 10.1 & 0.86 & 0.42 \\
\hline \multicolumn{7}{|c|}{ Heart girth } \\
\hline Initial & 77.6 & 79.3 & 79 & 79.3 & 0.65 & 0.22 \\
\hline Final & 91.4 & 94.3 & 94.2 & 93.0 & 1.19 & 0.19 \\
\hline Change & 13.8 & 15.0 & 15.2 & 13.7 & 1.26 & 0.68 \\
\hline \multicolumn{7}{|c|}{ Body barrel } \\
\hline Initial & 79.6 & 81.4 & 80.7 & 81.1 & 0.73 & 0.31 \\
\hline Final & 103.7 & 106.7 & 107.5 & 106.2 & 1.74 & 0.67 \\
\hline Change & 24.2 & 25.3 & 26.8 & 25.2 & 2.06 & 0.88 \\
\hline
\end{tabular}

No significant differences were detected for initial, weaning, and final skeletal growth indices $(P>0.05$; Table 3). These results are consistent with previous reports on processed sorghum and corn in calf starter (Schuh et al., 1970; Abdelgadir and Morrill., 1995; Zhang et al., 2010). Similar ingredients and composition of starter and DMI across treatments in the current study are likely the reason for these results. When Lesmeister and Heinrichs (2004) assessed minor changes observed in skeletal growth indices, no significant difference was detected, which is similar to the present study.

Least squares means of rumen fluid $\mathrm{pH}$ on d 35, 45, and 56 are presented Table 4. Slight decreases were noted in $\mathrm{pH}$ with advancing age, similar to a recent report by Rey et al. (2012). The results indicate, however, that rumen $\mathrm{pH}$ was not affected by treatments $(P>0.05)$. The present results are in disagreement with the observations reported by Khan et al. (2011) and Abdelgadir and Morrill (1995). This discrepancy may, in part, be explained by the fact that calves in the current study did not receive any forage in their diets. Porter et al. (2007) reported no difference in rumen $\mathrm{pH}$ caused by dietary intervention in calves fed high- or low-fiber calf starter. Further, Laarman and Oba (2011) reported no effect on rumen $\mathrm{pH}$ by calf starter, similar to the current study. Although the same group in another study (Laarman et al., 2012) reported significant relative changes in mRNA expression of genes involved in cholesterol synthesis and intracellular $\mathrm{pH}$ regulation in the ruminal epithelium for calves fed milk replacer + hay or milk replacer + hay and a calf starter. Alternatively, the low number of animals per treatment might have masked any potential differences among different processing methods in the present study.

Serum glucose, BUN, and BHBA concentrations in calves fed various types of processed barley, analyzed in 3 sets, including preweaning, postweaning, and overall period, are presented in Table 4. No treatment effect on blood metabolites measured over time was detected $(P>0.05$ for all). Serum glucose concentration was decreased in all calves with advancing age. On d 45, the serum glucose concentration tended to be lower in calves in the SRB group compared with the other groups. On d 35 and 56, however, the serum glucose concentration was numerically lowest in calves in the WB group compared with those in the CGB, SRB, and RB groups. Blood urea nitrogen concentration was increased in all calves with advancing age, but no treatment effects were observed. Overall, RB calves seemed to have had a lower BHBA concentration. On d 35, the greatest concentration of BHBA was observed in calves fed CGB, followed by WB, RB, and SRB. On d 45 , a similar trend was observed $(P=0.07)$. On d 56 , however, no tendency toward significance was observed.

In conclusion, our results demonstrate that different processing methods of barley used in this study had no 
Table 4. Least squares means for rumen $\mathrm{pH}$ and blood metabolites for Holstein calves receiving calf starter containing whole (WB), coarse ground (CGB), steam-rolled (SRB), or roasted (RB) barley

\begin{tabular}{|c|c|c|c|c|c|c|}
\hline \multirow[b]{2}{*}{ Item } & \multicolumn{4}{|c|}{ Calf starter } & \multirow[b]{2}{*}{ SEM } & \multirow[b]{2}{*}{$P$-value } \\
\hline & WB & CGB & $\mathrm{SRB}$ & $\mathrm{RB}$ & & \\
\hline \multicolumn{7}{|c|}{ Glucose (mg/dL) } \\
\hline $35 \mathrm{~d}$ of age & 83.0 & 92.25 & 88.25 & 91.5 & 5.5 & 0.62 \\
\hline $45 \mathrm{~d}$ of age & 78.75 & 83.5 & 66.0 & 88.5 & 5.7 & 0.07 \\
\hline $56 \mathrm{~d}$ of age & 65.25 & 76.5 & 80.75 & 86.75 & 6.85 & 0.20 \\
\hline \multicolumn{7}{|l|}{ BUN } \\
\hline $35 \mathrm{~d}$ of age & 9.6 & 8.9 & 8.4 & 8.2 & 1.23 & 0.86 \\
\hline $45 \mathrm{~d}$ of age & 11.0 & 11.9 & 11.1 & 12.6 & 0.61 & 0.25 \\
\hline $56 \mathrm{~d}$ of age & 12.15 & 11.0 & 11.2 & 11.6 & 0.71 & 0.68 \\
\hline \multicolumn{7}{|c|}{ Plasma BHBA } \\
\hline $35 \mathrm{~d}$ of age & 0.13 & 0.16 & 0.10 & 0.11 & 0.01 & 0.13 \\
\hline $45 \mathrm{~d}$ of age & 0.19 & 0.15 & 0.16 & 0.11 & 0.02 & 0.07 \\
\hline $56 \mathrm{~d}$ of age & 0.19 & 0.18 & 0.17 & 0.12 & 0.02 & 0.19 \\
\hline \multicolumn{7}{|l|}{ pH } \\
\hline $35 \mathrm{~d}$ of age & 5.87 & 5.35 & 5.55 & 5.98 & 0.19 & 0.15 \\
\hline $45 \mathrm{~d}$ of age & 5.62 & 5.25 & 5.37 & 5.78 & 0.18 & 0.51 \\
\hline $56 \mathrm{~d}$ of age & 5.59 & 5.36 & 5.25 & 5.60 & 0.16 & 0.37 \\
\hline
\end{tabular}

detectable effect on performance of dairy calves under our experimental conditions. However, the number of calves may have limited the statistical power to identify significant differences among treatments.

\section{ACKNOWLEDGMENTS}

The authors thank Isfahan University of Technology (Isfahan, Iran) and Foodeh dairy farm (Isfahan, Iran) for providing research facilities.

\section{REFERENCES}

Abdelgadir, I. E. O., and J. L. Morrill. 1995. Effect of processing sorghum grain on dairy calf performance. J. Dairy Sci. 78:2040-2046.

AOAC (Association of Official Analytical Chemists). 1990. Official Methods of Analysis. 15th ed. AOAC, Washington, DC.

Harrison, H. N., R. G. Warner, E. G. Sander, and J. K. Loosli. 1960 Changes in the tissue and volume of the stomachs of calves following the removal of dry feed or consumption of inert bulk. J. Dairy Sci. 43:1301-1312.

Huntington, G. B. 1997. Starch utilization by ruminants: From basics to the bunk. J. Anim. Sci. 75:852-867.

Khan, M. A., D. M. Weary, and M. A. G. von Keyserlingk. 2011. Hay intake improves performance and rumen development of calves fed higher quantities of milk. J. Dairy Sci. 94:3547-3553.

Khan, M. A., H. J. Lee, W. S. Lee, H. S. Kim, S. B. Kim, K. S. Ki, S. J. Park, J. K. Ha, and Y. J. Choi. 2007. Starch source evaluation in calf starter: I. Feed consumption, body weight gain, structural growth, and blood metabolites in Holstein calves. J. Dairy Sci. 90:5259-5268.

Laarman, A. H., and M. Oba. 2011. Short communication: Effect of calf starter on rumen $\mathrm{pH}$ of Holstein dairy calves at weaning. J. Dairy Sci. 94:5661-5664.
Laarman, A. H., T. Sugino, and M. Oba. 2012. Effect of starch content of calf starter on growth and rumen $\mathrm{pH}$ in Holstein calves during the weaning transition. J. Dairy Sci. 95:4478-4487.

Larson, L. L., F. G. Owen, J. L. Albright, R. D. Appleman, R. C. Lamb, and L. D. Muller. 1977. Guidelines toward more uniformity in measuring and reporting calf experimental data. J. Dairy Sci. 60:989-991.

Lesmeister, K. E., and A. J. Heinrichs. 2004. Effects of corn processing on growth characteristics, rumen development, and rumen parameters in neonatal dairy calves. J. Dairy Sci. 87:3439-3450.

Owens, F. N., D. S. Secrist, W. J. Hill, and D. R. Gill. 1997. The effect of grain source and grain processing on performance of feedlot cattle: A review. J. Anim. Sci. 75:868-879.

Porter, J. C., R. G. Warner, and A. F. Kertz. 2007. Effect of fiber level and physical form of starter on growth and development of dairy calves fed no forage. Prof. Anim. Scientist 23:395-400.

Reis, R. B., and D. K. Combs. 2000. Effects of corn processing and supplemental hay on rumen environment and lactation performance of dairy cows grazing grass-legume pasture. J. Dairy Sci. 83:2529-2538.

Rey, M., F. Enjalbert, and V. Monteils. 2012. Establishment of ruminal enzyme activities and fermentation capacity in dairy calve from birth through weaning. J. Dairy Sci. 95:1500-1512.

Schuh, J. D., J. O. A. Lima, W. H. Hale, and B. Theurer. 1970. Steamprocessed flaked grains versus steam-rolled grains for dairy calves. J. Dairy Sci. 53:475-479.

Theurer, C. B. 1986. Grain processing effects on starch utilization by ruminants. J. Anim. Sci. 63:1649-1662.

Van Soest, P. J., J. B. Robertson, and B. A. Lewis. 1991. Methods for dietary, neutral detergent fiber, and nonstarch polysaccharides in relation to animal nutrition. J. Dairy Sci. 74:3583-3597.

Wang, Y., D. Greer, and T. A. McAllister. 2003. Effects of moisture, roller setting, and saponin-based surfactant on barley processing, ruminal degradation of barley, and growth performance by feedlot steers. J. Anim. Sci. 81:2145-2154.

Zhang, Y. Q., D. C. He, and Q. X. Meng. 2010. Effect of a mixture of steam-flaked corn and soybeans on health, growth, and selected blood metabolism of Holstein calves. J. Dairy Sci. 93:2271-2279. 